УДК 349.42:338.432:338.439.6

DOI https: / / doi.org/10.32837/yuv.v0i6.2043

\author{
Д. Луц, \\ кандидат юридичних наук, \\ доцент кафедри цивільного права \\ Запорізького національного університету \\ Д. Гречковський, \\ магістр права, \\ молодший науковий співробітник науково-дослідної частини \\ Запорізького національного університету
}

\title{
ПОНЯТТЯ ТА СТРУКТУРА ОРГАНІЗАЦІЙНО-ПРАВОВОГО МЕХАНІЗМУ ПУБЛІЧНОГО УПРАВЛІННЯ В СФЕРІ ВИРОБНИЦТВА ОРГАНІЧНОЇ СІЛЬСЬКОГОСПОДАРСЬКОЇ ПРОДУКЦІї
}

Протягом 2020 р. в Україні було досягнуто суттєвих позитивних зрушень у сфері правового регулювання виробництва та сертифікації органічної продукції. Зокрема, 23 жовтня 2020 р. Кабінет Міністрів України прийняв довгоочікувану Постанову «Про затвердження Порядку сертифікації органічного виробництва та / або обігу органічної продукції та внесення змін до Постанови Кабінету Міністрів України від 23 жовтня 2019 р. № 970» № 1032. Фактично сьогодні процедуру такої сертифікації здійснюють іноземні компанії, яких нараховується близько 20. Також на момент написання статті активно триває обговорення Програми підтримки аграрного сектору на 2021-2023 рр.

Як слушно стверджує Н.О. Багай, «теоретично систематизовані знання $€$ необхідною передумовою, засобом для відкриття нових знань, а тому без використання наукових знань неможливий подальший поступ науки» [3, с. 11]. Особливо актуальною наведена теза $є$ сьогодні, коли відбувається значна частина перетворень в аграрно-правовій сфері загалом та у сфері виробництва органічної продукції зокрема, що актуалізує питання підходів до правових механізмів публічного управління у сфері аграрних відносин.

У вітчизняній правовій науці спостерігається певний брак праць, які би приділяли увагу досліджуваній тематиці. Водночас наявні суттєві напрацювання таких учених, як О.Г. Бондар, А.П. Гетьман, В.Ю. Уркевич, М.В. Шульга, В.В. Носік, В.М. Ермоленко, А.С. Овчаренко, Т.К. Оверковська. На окрему увагу заслуговує монографія «Органічне сільськогосподарське виробництво в Україні: правові засади ведення» (Харків, 2020 р.).

Перш ніж предметно перейти до розкриття змісту вибраної теми, детально зупинимось на змісті поняття «публічне управління». Сьогодні у правовій науці спостерігається певний відхід від категорії «державне управління» на користь поняття «публічне управління».

Вперше поняття «публічне адміністрування» ("public management") у науковий обіг увів англійський дослідник державного управління Десмонд Кілінг у 1972 році, визначивши його як пошук у найкращий спосіб використання ресурсів для досягнення пріоритетних цілей державної 
політики [4, с. 48]. Як слушно зазначає K.I. Рибалка, «в юридичній літературі поняття «публічне управління» часто ототожнюють із поняттями «публічне адміністрування», «державне управління», а це призводить до неправильного розуміння чинників його формування та розвитку» [5, с. 299].

Суттєва відмінність полягає в тому, що до кола суб'єктів публічного управління віднесені органи місцевого самоврядування та їх посадові особи, організаційно-розпорядча діяльність яких $є$ вкрай важливою для ведення органічного сільського господарства, тому, вважаємо, що оперування саме поняттям «публічне управління у сфері виробництва органічної сільськогосподарської продукціï» вбачається більш вдалим та конструктивним.

Водночас $€$ ще один вагомий аспект, на який цілком слушно звертає увагу О.Г. Бондар. На думку вченого, «введення у науковий обіг категорії «публічне управління у земельній сфері» є доцільним, однак не лише 3 огляду на розширення суб'єктного складу органів управління. Йдеться про те, що для сучасної адміністративно-правової науки є характерною не просто відмова від догматичних засад радянського адміністративного права, винятково «державоцентристських», але й запозичення принципів, понять та ключових категорій так званого європейського адміністративного права» [6].

Отже, у нашій роботі під публічним управлінням у сфері виробництва органічної сільськогосподарської продукції ми розуміємо діяльність суб'єктів публічної адміністрації (органів виконавчої влади, місцевого самоврядування, інших суб'єктів, яким делеговані адміністративно-управлінські та публічно-сервісні функції у сфері виробництва, обігу та маркування органічної продукціі), спрямовану на реалізацію політики у сфері органічного виробництва, обігу та маркування органічної продукції.
Як відомо, публічне управління здійснюється через призму організаційно-правового механізму, який містить низку елементів.

Аналіз відповідних наукових праць дає підстави стверджувати, що під механізмом публічного управління у сфері органічного виробництва, обігу та маркування органічної продукціі слід розуміти систему органів виконавчої влади, місцевого самоврядування, інших суб'єктів, яким делеговані адміністративно-управлінські та публічно-сервісні функції у сфері аграрних відносин, які за допомогою низки інструментів (засобів, важелів, методів, процедури, правових норм, стимулів, способів, функцій, принципів, заходів тощо) та наявних ресурсів забезпечують вплив на сферу виробництва органічної сільськогосподарської продукціі, формування відповідної політики держави та реалізують покладені на них завдання у сфері органічного виробництва.

Ми виходимо з того, що організаційно-правовий механізм у сфері виробництва органічної сільськогосподарської продукції складається з нормативного, програмного, інституційного, функціонального, фінансовоекономічного елементів, а також охорони земель.

Нормативне регулювання у сфері виробництва органічної сільськогосподарської продукції є одним з основних елементів у механізмі управління. Можемо стверджувати, що воно здійснюється в таких напрямах:

- встановлення вимог до органічної продукції;

- визначення основних напрямів розвитку у цій сфері;

- сертифікація органічного виробництва;

- державна підтримка розвитку органічного виробництва.

Хоча Конституція України не містить прямих згадок про органічну продукцію, відповідно до ст. $42 \mathrm{KoH}-$ ституціі, «держава захищає права споживачів, здійснює контроль за якістю 
і безпечністю продукції та усіх видів послуг і робіт, сприяє діяльності громадських організацій споживачів» [7]. В цьому аспекті зазначимо, що органи державної влади здійснюють контроль за проведенням органічного виробництва та стимулюють приріст відповідної продукції як такої, яка є кращою та більш корисною для споживання.

Базисним для органічного напряму вітчизняного сільського господарства із 2 серпня 2019 р. є Закон «Про основні принципи та вимоги до органічного виробництва, обігу та маркування органічної продукції», який визначає основні принципи та вимоги до органічного виробництва, обігу та маркування органічної продукції, засади правового регулювання органічного виробництва, обігу органічної продукції та функціонування ринку органічної продукції, правові основи діяльності центральних органів виконавчої влади, суб'єктів ринку органічної продукції та напрями державної політики у зазначених сферах [2].

Цілком повністю поділяємо позицію Х.А. Григор'євої, яка обстоює необхідність внесення змін до Закону про органічне виробництво, у якому «мають бути закріплені, по-перше, принципи протекціонізму органічного виробництва та пріоритетності цього напряму в сільському господарстві; по-друге, передбачені окремі норми, які присвячені державній підтримці та гарантують обов'язковість їі надання» [8, с. 477].

Іншими законами, якими здійснюється регулювання у відповідній галузі, є Закони «Про основні принципи та вимоги до безпечності та якості харчових продуктів», «Про аквакультуру», «Про ветеринарну медицину», «Про державний контроль за дотриманням законодавства про харчові продукти, корми, побічні продукти тваринного походження, здоров'я та благополуччя тварин».

Значне коло питань регулюється міжнародними нормами права. Зокрема, виділимо Постанову
Ради (ЄС) від 28 червня 2007 р. № 834/2007 стосовно органічного виробництва і маркування органічних продуктів, скасування Постанови (ЄEC) № 2092/91, Постанову Комісії (ЄС) «Детальні правила щодо органічного виробництва, маркування і контролю для впровадження Постанови Ради (ЄC) № 834/2007 стосовно органічного виробництва і маркування органічних продуктів» № 889 / 2008 від 5 вересня 2008 р., Постанову (EC) № $882 / 2004$ Європейського парламенту та Ради від 29 квітня 2004 р. щодо здійснення офіційного контролю для забезпечення відповідності законам стосовно кормів та харчових продуктів, правил щодо здоров'я та належного утримання тварин тощо.

Значна частина положень закону потребує конкретизації у підзаконних нормативно-правових актах, серед яких виділимо нещодавно прийняту Постанову КМУ «Про затвердження Порядку сертифікації органічного виробництва та/або обігу органічної продукції та внесення змін до Постанови Кабінету Міністрів України від 23 жовтня 2019 р. № 970», якою визначається механізм сертифікації органічного виробництва та/ або обігу органічної продукції, видачі сертифіката, його дубліката та форми [9].

Вагомого значення набувають рішення органів місцевого самоврядування щодо розроблення та прийняття відповідних програм щодо підтримки органічного виробництва.

Як можна помітити, у нашому дослідженні виділяється програмний елемент. Це є своєрідною новелою, яку ми пов'язуємо з тим, що саме загальнодержавна програма може акцентувати увагу на окремих аспектах діяльності у відповідній сфері та закласти кошти на підтримку відповідної галузі. Зокрема, відповідно до ст. 8 ЗУ «Про основні принципи та вимоги до органічного виробництва, обігу та маркування органічної продукції, державна підтримка може надаватися операторам у рамках загальнодержавних та 
регіональних програм за рахунок і в межах видатків за бюджетними програмами, спрямованими на підтримку розвитку сільськогосподарських товаровиробників [2].

Як йдеться У ст. 1 ЗУ «Про державні цільові програми», державна цільова програма - це комплекс взаємопов'язаних завдань і заходів, які спрямовані на вирішення найважливіших проблем розвитку держави, окремих галузей економіки або адміністративно-територіальних одиниць, здійснюються 3 використанням коштів Державного бюджету України та узгоджені за строками виконання, складом виконавців, ресурсним забезпеченням [10].

Варто зазначити, що сьогодні в Україні відсутня відповідна програма з розвитку органічного виробництва, що, на наше переконання, є суттєвим упушенням. Водночас окремі аспекти розвитку органічного виробництва знаходять відтворення у програмах підтримки АПК. Зокрема, 17 вересня на засіданні Комітету Верховної Ради України з питань аграрної та земельної політики було презентовано пропозиції Мінекономіки щодо державної підтримки аграрної галузі на 20212023 рр. Стратегія міністерства передбачає доповнення підтримки новими програмами та розширення напрямів за чинними програмами. Зокрема, планується 7 таких основних програм підтримки:

- фінансова підтримка заходів в АПК (кредити, страхування);

- підтримка виробництва нішевих культур (продовольча безпека);

- підтримка фермерства;

- підтримка садівництва, виноградарства, хмелярства;

- картоплярство;

- підтримка тваринництва;

- часткова компенсація вартості СГ техніки.

Як зазначає заступник міністра Мінекономіки, «ми адаптували програми до нових умов та потреб виробників, додавши такі напрями, як стра- хування врожаю, підтримка нішевого та органічного виробництва, бджільництва» [11].

Задля комплексного розгляду піднятої тематики потребує дослідження наявність відповідних регіональних програм. Одразу варто окреслити, що регіональні програми доцільно поділити на групи загального спрямування та галузевого спрямування.

До програм загального спрямування варто віднести комплексні програми агропромислового розвитку відповідних територій (Комплексна програма розвитку агропромислового комплексу Волинської області на 2016-2021 pp. [12], Програма розвитку агропромислового комплексу Житомирської області на 2016-2020 рр. [13], Комплексна програма розвитку агропромислового комплексу та сільських територій Івано-Франківської області на 20162020 pp. [14]).

Як програму галузевого спрямування можна навести програму фінансової підтримки органічного виробництва в Чернігівській області на 2015-2020 рр., метою якої є збільшення частки органічної продукції у загальному обсязі валової продукціï сільського господарства області та забезпечення населення продуктами харчування, що безпечні для здоров'я [15].

Отже, вважаємо, що прийняття відповідної державної цільової програми $з$ розвитку органічного виробництва та регіональних програм сприятиме подальшому розвитку галузі та іï фінансовому забезпеченню.

Говорячи про інституційний та функціональний елементи, можемо стверджувати, що ключове місце у системі інституційного забезпечення публічного управління у досліджуваній нами сфері, відповідно до ст. 11 Закону про органічне виробництво, належить ЦОВВ, що забезпечує формування та реалізацію державної аграрної політики (сьогодні це Міністерство розвитку економіки, торгівлі 
та сільського господарства). Саме на нього покладаються забезпечення формування та реалізації державної політики у сфері органічного виробництва, обігу та маркування органічної продукції; здійснення державного управління та регулювання у цій сфері тощо.

Серед елементів системи інституційного забезпечення публічного управління у сфері органічного сільського господарства варто окремо виділити Національне агентство з акредитації України (далі - НААУ). Згідно з Положенням про це агентство, затвердженим Наказом Міністерства економічного розвитку і торгівлі України від 13 червня 2020 р. № 1318, воно є національним органом України з акредитації органів з оцінки відповідності [16].

Відповідно до ч. 2 ст. 6 ЗУ «Про основні принципи та вимоги до органічного виробництва, обігу та маркування органічної продукції, передбачено створення єдиної системи сертифікації органічного виробництва та/або обігу та державного контролю органічного виробництва, обігу та маркування органічної продукції, отже, окремий розділ VI «Сертифікація та органи сертифікації унормовує відповідні правовідносини. Органи сертифікації повинні бути акредитовані в НАAУ.

Іншим важливим органом $є$ Державна служба України з питань безпечності харчових продуктів та захисту споживачів. У Положенні про Держпродспоживслужбу, затвердженому Постановою Кабінету Міністрів України від 2 вересня 2015 р. № 667, серед спектру основних завдань цього ЦОВВ передбачено, зокрема, здійснення державного нагляду (контролю) за діяльністю суб'єктів господарювання, які здійснюють виробництво, перевезення, зберігання, реалізацію органічної продукції (сировини) [17].

Варто акцентувати увагу на тому, що фінансово-економічний елемент безпосередньо пов'язаний із функці- онуванням відповідних програм, які мають передбачати певні компенсації виробникам органічної сільськогосподарської продукції.

Вагому роль у процесі виробництва органічної продукції відіграє якість земельних ділянок, яка залежить від комплексу заходів, спрямованих на забезпечення охорони земель. Зокрема, оператор виробництва продукції має додавати для сільськогосподарських угідь та місць збирання органічних об'єктів рослинного світу (за наявності) дату припинення використання на відповідних земельних ділянках речовин, інших, ніж ті, що зазначені в переліку речовин (інгредієнтів, компонентів), що дозволяється використовувати у процесі органічного виробництва та які дозволені до використання у гранично допустимих кількостях, затвердженому Мінекономіки.

3 викладеного нами матеріалу випливає, що механізм публічного управління у сфері виробництва органічної сільськогосподарської продукції $€$ доволі складним і містить різноманітні елементи, які є тісно пов'язаними між собою. Вважаємо, що подальший розвиток органічного виробництва в Україні залежить саме від ефективності функціонування відповідного організаційно-правового механізму.

Однією з вимог, які висуває перед Україною європейська спільнота, є вирішення питання переходу на європейські стандарти з виробництва сільськогосподарської продукції. Йдеться не просто про втілення нових технологій переробки, але й про запровадження новітніх технологій виробництва сільськогосподарської продукиї. Одним із таких перспективних напрямів у сільському господарстві є виробництво органічної сільськогосподарської продукиіi.

Актуалізація питання зумовлена тим, що заохочення сучасного та сталого сільськогосподарського 
виробництва щзодо поширення методів органічного виробництва й використання біотехнологій передбачено ст. 404 Глави 17 Угоди про Асоиіацію між Україною та Європейським Союзом.

Констатовано, що спостерігаються значні тенденції щодо збільшення виробниитва органічної сільськогосподарської продукціі в Україні. Органи державної влади вживають заходів щзодо популяризаціі органічного виробництва як пріоритету розвитку аграрного сектору економіки України, споживання органічної продукції в Україні, а також процедури внутрішньоі торгівлі та перспективи розширення експорту органічної продукціі українських операторів ринку [1].

Проте Україна, маючи величезнuй потенціал у иій сфері, суттево відстає від більшості зарубіжних держав за темпами розвитку органічного напряму сільського господарства та обсягами його виробництва.

Розділ III Закону «Про основні принципи та вимоги до органічного виробництва, обігу та маркування органічної продукиії» [2] встановлюе загальні засади державного регулювання у сфері органічного виробництва, обігу та маркування органічної продукиї, а окремий розdiл IV иього Закону визначає повноваження органів виконавчої влади, що здійснюють державне управління та регулювання у зазначеній сфері. Вважаємо, що має йтися не просто про державне регулювання у сорері органічного виробниизтва, а про організаційно-правовий механізм публічного управління у сорері виробниитва органінної сільськогосподарської продукиії, адже з огляду на проблеми з виділенням коштів із державного бюджету на відповідні напрями гостро постає питання необхідності прийняття та виконання регіональних програм, які спрямовуються на підтримку органічного виробництва. Це зачі- пає більи широкий спектр правового регулювання, ніж суто повноваження органів державної влади.

Вищевикладене детермінує необхідність дослідження поняття та структури організаційно-правового механізму публічного управління у сфері виробництва органічної сільськогосподарської продукції.

Ключові слова: органічне виробництво, продовольча безпека, сертифікація органічного виробництва, публічне управління, організаційно-правовий механізм публічного управління, державна цільова програма.

Luts D., Grechkovsky D. The concept and structure of the organizational and legal mechanism of public administration in the field of organic agricultural production

One of the requirements of the European community towards Ukraine is to resolve the issue of transition to European standards for agricultural production. This presupposes not just implementation of new processing technologies, but also the introduction of new technologies for agricultural production. One of such promising areas in agriculture is the production of organic agricultural products.

The actualization of the issue is due to the fact that the promotion of modern and sustainable agricultural production in terms of dissemination of organic production methods and the use of biotechnology is provided by Article 404 of Chapter 17 of the Association Agreement between Ukraine and the European Union.

It is stated that there are significant trends in increasing the production of organic agricultural products in Ukraine. Public authorities, for their part, take measures to promote organic production as a priority for the development of the agricultural sector of Ukraine's economy, consumption of organic products in Ukraine, as well as domestic trade procedures and prospects for expanding exports of 
organic products of Ukrainian market operators.

Nevertheless, Ukraine, having a huge potential in this area, falls far behind most foreign countries in the pace of development of the organic direction of agriculture and the volume of its production.

Section III of the Law "On Basic Principles and Requirements for Organic Production, Circulation and Labeling of Organic Products" establishes the general principles of state regulation in the field of organic production, circulation and labeling of organic products, and separate section $I V$ of this Law defines the powers of executive bodies that carry out management and regulation in this area. We believe that it should be not just about state regulation in the field of organic production, but about the organizational and legal mechanism of public administration in the field of organic production, because, considering the problems with allocating funds from the state budget to relevant areas, there arises a question of adoption and implementation of regional programs aimed at supporting organic production. This, in turn, affects a wider range of legal regulation than the purely powers of public authorities.

The abovementioned determines the necessity to study the concept and structure of the organizational and legal mechanism of public administration in the field of production of organic agricultural products.

Key words: organic production, food security, certification of organic production, public administration, organizational and legal mechanism of public administration, state target program.

Література
1. Органічне виробнищтво у
грополітиці розглядають як
ритетіо-
розвитку аграрного

тору української економіки. URL: https: / / cherk-consumer.gov.ua/ novyny /619-orhanichne-vyrobnytstvo-uminahropolitytsi-rozhliadaiut-iak-priorytetrozvytku-ahrarnoho-sektoru-ukrainskoiekonomiky (дата звернення: 22.12.2020).

2. Про основні принципи та вимоги до органічного виробництва, обігу та маркування органічної продукиії : Закон України від 10 липня 2018 р. № 2496-VIII. URL: https://zakon.rada. gov.ua/laws/show/2496-19 (Jama звернення: 22.12.2020).

3. Багай Н.О. Розвиток науки аграрного права України : дис. ... канд. юрид. наук : спеи. 12.00 .06 ; Львівський національний університет ім. Івана Франка. Львів, 2002. 243 с.

4. Максіменцева Н.О. Публічне адміністрування у галузі використання $i$ охорони надр в Україні : монографія. Дніпро : Ліра, 2018. 464 c.

5. Рибалка К.І. Публічне управління в галузі використання та охорони земель запасу України: адміністративноправовий аспект. Порівняльно-аналітичне право. 2018. № 6. С. 299-302.

6. Бондар О.Г. Публічне управління у сфері використання та охорони земель в Україні: актуальні проблеми правового та інституційного забезпечення. Право України. 2020. Bun. 5. C. 43-63.

7. Конституція України: Закон України від 28 червня 1996 р. № $254 \kappa / 96-B P$. Відомості Верховної Ради України. 1996. № $30 . \mathrm{Cm}$. 141 .

8. Григор'єва Х.A. Державна підтримка сільського господарства України: проблеми правового забезпечення : монографія. Херсон: Видавничий дім «Гельветика, 2019. 596 c.

9. Про затвердження Порядку сертифікації органічного виробництва та/ або обігу органічної продукиї та внесення змін до Постанови Кабінету Міністрів України від 23 жовтня 2019 р. № 970 : Постанова Кабінету міністрів України віа 21 жовтня 2020 р. № 1032. URL: https: / / zakon.rada.gov.ua/laws / show/1032-2020-\%D0\%BF\#Text (Jama звернення: 22.12.2020).

10. Про державні цільові програми : Закон України від 18 березня 2004 p. № 1621-IV. URL: https: / / zakon. rada.gov.ua/laws/show/1621-15\#Text (дата звернення: 22.12.2020).

11. На аграрному комітеті представили програми держпідтримки 


\section{ЮРИАИЧНИЙ ВІСНИК, 2020/6}

АПK на 2021-2023 pp. URL: https:// wrw.me.gov.ua / News / Detail lang $=u k$ $U A \& i d=f 6 e e 5274-a 9 b 8-4731-a 3 f 2-a b 97171 c$ d91e\&title $=$ NaAgrarnomuKomitetiPredstavi liProgramiDerzhpidtrimkiApkNa2021-2023Roki (дата звернення: 22.12.2020).

12. Про Комплексну програму розвитку агропромислового комплексу Волинської області на 2016-2021 рр. : Рішення Волинської обласної ради від 10 березня 2016 p. № 3/23. URL: http: / / agrovolyn. gov.ua/article /kompleksna-programarozvytku-agropromyslovogo-kompleksuvolynskoyi-oblasti-na-2016-2021-roky (дата звернення: 22.12.2020).

13. Про Програму розвитку агропромислового комплексу Житомирської області на 2016-2020 рр. : Рішення Житомирської обласної ради від 7 березня 2018 р. № 938. URL: https:// zt.gov.ua/index.php /ofitsijni-dokumenti/ normativni-dokumenti / rishennya-oblasnojiradi / 11638-No-938-nро-програму-розвитку-агропромислового-комплексу-житомирської-області-на-2016-2020-роки.html (дата звернення: 22.12.2020).

14. Про Комплексну програму розвитку агропромислового комплексу та сільських територій Івано-Франківської області на 2016-2020 рр. : Рішення
Івано-Франківської обласної ради від 16 жовтня 2015 р. № 1830-39/2015. URL: http: / / www.if.gov.ua / files / uploads / КОМПЛЕКСНА\% 20ПРОГРАМА_-фін.pdf (дата звернення: 22.12.2020)

15. Про програму фінансової підтримки органічного виробництва в Чернігівській області на 2015-2020 рр. : Рішення Чернігівської обласної ради від 29 квітня 2015 p. URL: https://chor. gov.ua/normationi-dokumenti/rishennya/ item / 2803-pro-prohramufinansovoipidtrymky-orhanichnoho-vyrobnytstva-vcher (дата звернення: 22.12.2020).

16. Про затвердження нової редакиї Положення про Національне агентство з акредитації України : Наказ Міністерства розвитку економіки, торгівлі та сільського господарства України від 13 липня 2020 p. № 1318. URL: https: / / zakon.rada. gov.ua / rada / show / v1318915-20\#Text (дата звернення: 22.12.2020).

17. Про затвердження Положення про Державну службу України з питань безпечності харчових продуктів та захисту споживачів : Постанова Кабінету Міністрів України від 2 вересня 2015 р. № 667. URL: https: / / zakon.rada.gov.ua/ laws / show /667-2015-\%D0\% BF\#Text (дата звернення: 22.12.2020) 